\title{
SELF-EVALUATED ADHD SYMPTOMS AS RISK ADAPTATION FACTORS IN ELEMENTARY SCHOOL CHILDREN
}

Tena VELKI, Zvonimir UŽAREVIĆ, Snježana DUBOVICKI Faculty of Education, Osijek

UDK: 373.3.091.212:159.952.6

373.3.04:616.89-008.47

Izvorni znanstveni rad

Primljeno: 26. 2. 2018.

Previous studies have shown that students with ADHD symptoms are more likely to have problems in all aspects of adaptation. The aim of this study is to identify ADHD symptoms that predict maladjustment in the general population of students. Hyperactivity, impulsiveness and inattention were examined with respect to academic, social and emotional adjustment. Elementary school students (average age $M=12.72, S D=1.62$ ) participated in the study $(N=501)$. The instruments used were: Hyperactivity-Impulsivity-Attention Scale, Croatian version of Self-efficacy questionnaire for children, Emotional competence questionnaire, self-assessment of peer acceptance and school success. Inattention was a significant predictor of problems in all aspects of adaptation, i.e. academic $(\beta=-0.317$; $\beta=-0.528 ; p<0.001)$, social $(\beta=-0.269 ; \beta=-0.430$;

$p<0.001)$ and emotional adjustment $(\beta=-0.225 ; \beta=-0.367$; $p<0.01)$. Impulsiveness was only a significant predictor of academic self-efficacy $(\beta=-0.187, p<0.01)$, whereas hyperactivity was only significant for emotional competence $(\beta=-0.174, p<0.05)$. Since inattention proved to be a dominant problem, it is recommended that experts working with children make an effort to increase attention and concentration as a prevention strategy for adaptation problems of all students.

Keywords: hyperactivity, impulsiveness, inattention, academic adjustment, social adjustment, emotional adjustment

$\triangle \quad$ Tena Velki, Josip Juraj Strossmayer University of Osijek, Faculty of Education, Cara Hadrijana 10, 31000 Osijek, Croatia. E-mail: tena.velki@gmail.com 
Numerous previous studies have shown that ADHD children show adaptation problems, primarily academic, social and emotional difficulties (Bussing, Mason, Bell, Porter, \& Garvan, 2010; Bussing et al., 2012; Defoe, Farrington, \& Loeber, 2013; Velki \& Dudaš, 2016), which make their everyday functioning at home and school harder. Moreover, recent studies have shown that children suspected of having ADHD, i.e. children with more salient symptoms of ADHD but not exceeding the critical value for diagnosis, also show difficulties in daily functioning. Thus, studies show that children suspected of having ADHD perform lower in all domains of academic achievement - reading, writing, mother tongue and math (August, Ostrander, \& Bloomquist, 1992; Bussing et al., 2010; Hong et al., 2014), have more problems with attention during formal exams and show significantly poorer results on tests of executive functions (Brown \& Casey, 2016; Hong et al., 2014), drop out of school higher than average, have more psychosocial problems, problems in peer relations and internalized problems (Norén Selinus et al., 2016), have fewer friends, make poor-quality friendships and earn negative reputation among peers (Rielly, Craig, \& Parker, 2006). Generally speaking, their social functioning has been shown to be less successful with more problems in the domain of emotion control (Gudjonsson, Sigurdsson, Eyjolfsdottir, Smari, \& Young, 2009; Norvilitis, Sun, \& Zhang, 2010), poorer behavioral and emotional control (Hong et al., 2014), lower level of empathy (Groen, den Heijer, Fuermaier, Althaus, \& Tucha, 2017), and, also, they show more internalized and externalized disorders (Brown \& Casey, 2016; Bussing et al., 2010) and generally greater comorbidity (Cho et al., 2009).

In the case of school-age children symptoms of inattention have proved to be crucial in predicting academic failure. Problems with forgotten homework, inability to concentrate on school assignments, difficulty in copying from blackboard, truancy, dropping out of school and poor academic self-efficacy altogether lead to poorer school achievement even though these students may be of average or above average intellectual abilities (Barkley, 2000; Pagani et al., 2008; Passolt, 2002; Weyandt \& DuPaul, 2008; Young, Heptinstall, Sonuga-Barke, Chadwick, \& Taylor, 2005).

In addition to the symptoms of inattention, the symptoms of impulsivity proved to be significant for poorer academic performance, even at college level (Frazier, Youngstrom, Glutting, \& Watkins, 2007). Children with more salient symptoms of impulsivity, especially when combined with aggressive 
DRUŠ. ISTRAŽ. ZAGREB GOD. 28 (2019), BR. 3, STR. 503-522

VELKI, T., UŽAREVIĆ, Z., DUBOVICKI, S.: SELF-EVALUATED ADHD.. behavior, show poorer academic achievement, which is the result of a common neurobiological background, i.e. deficiency of executive functions, short response times to external stimuli and unbalanced emotional functioning (Sjöwall \& Thorell, 2014).

In a longitudinal study of ADHD girls, the main risk factor for poor school success was a combination of symptoms of hyperactivity and inattention (Young et al., 2005). Additionally, the same group displayed a lower degree of self-confidence in decision-making and planning. Another longitudinal study with children aged 12 to 26 years at follow-up confirmed that symptoms of hyperactivity and inattention led to poorer academic achievement and more frequent drop outs from further education (Galéra, Melchior, Chastang, Bouvard, \& Fombonne, 2009). Additional research showed that children with more salient symptoms of hyperactivity and inattention displayed poorer academic and social functioning and less developed learning skills (Norvilitis et al., 2010; Norwalk, Norvilitis, \& MacLean, 2009), poorly developed academic self-efficacy, weaker results in cognitive and achievement tasks, and problems in processing information and with executive functions (DuPaul \& Langberg, 2015; Todd et al., 2002).

The symptoms of impulsivity have proved to be particularly challenging for social and emotional functioning of children since these are most often associated with violent and aggressive behavior towards peers (McQuade \& Hoza, 2015; Velki \& Romstein, 2016). Children that are more impulsive are prone to interrupt others in conversations, to a reckless and ignorant behavior during interaction and, also, a lack of recognition of emotions in others, which results in conflicts during interaction; in other words, they show deficits in verbal behavior and communication skills (Corkum, Corbin, \& Pike, 2010). As a consequence of this behavior, their peers tend to exclude impulsive children from play and social activities, which increases the risk of development of addiction and depression in later years (Barkley, 2015; Defoe et al., 2013; Lachenmeier, 2014). Peers prefer to make friends with children who are easier to establish a relationship with, or show a preference for a relationship in which they need to invest less energy than when dealing with impulsive friends who are being unpredictable (Bartolac, 2013).

Numerous studies have pointed at age and gender differences in ADHD and indicated the disorder as more common in boys than in girls (Quinn \& Wigal, 2004). However, the number of people diagnosed with ADHD grows with age whereas gender differences are reduced (Velki, 2012). The study 
DRUŠ. ISTRAŽ. ZAGREB GOD. 28 (2019), BR. 3, STR. 503-522

VELKI, T., UŽAREVIĆ, Z., DUBOVICKI, S.: SELF-EVALUATED ADHD.. of children suspected of ADHD concluded that age had a mediating effect in the connection between symptoms of ADHD and academic achievement. For self-evaluated hyperactivity, age had a full mediating role, i.e. as the students' age increased, there was no correlation between self-evaluated hyperactivity and academic achievement. In addition, age had a partially mediating role in the connections between self-evaluated inattention with academic achievement and academic self-efficacy, i.e. as the students' age increases, the correlation between self-evaluated symptoms of inattention and both academic self-efficacy and academic achievement, becomes weaker (Velki \& Vrdoljak, 2019). The explanation is found in the fact that ADHD is the most commonly diagnosed when children start school where they are faced with increased developmental tasks. This usually leads to the recognition of hyperactive boys and the most frequently diagnosed subtypes of ADHD are the combined subtype or predominantly hyperactive/impulsive subtype (Moldavsky, Groenewald, Owen, \& Sayal, 2012). The second identification period of ADHD occurs when students move to upper grades of elementary school, when school requirements get even more demanding and complex. The predominantly inattentive subtype of ADHD is diagnosed more often at this time as problems with inattention significantly disrupt the daily functioning of the child (Biederman et al., 2002; Cantwell, 1996; Ramtekkar, Reiersen, Todorov, \& Todd, 2010; Rucklidge, 2010). This subtype of the disorder is more commonly found in girls (Gershon, 2002).

Previous research has mostly focused on children and adults who have been diagnosed with ADHD, not on those showing only some individual salient symptoms (Balázs \& Keresztény, 2013). Children suspected of having ADHD have more salient symptoms of the disorder, which may present a problem for their everyday functioning (Velki \& Dudaš, 2016), and, because they lack a diagnosis, they are not involved in treatment or prevention programs. Furthermore, numerous studies have shown that manifestation of a particular ADHD symptom leads to academic, social and / or emotional difficulties (Frazier et al., 2007; Norvilitis et al., 2010; Norwalk et al., 2009; Weyandt \& DuPaul, 2008; Young et al., 2005), although findings are not always consistent when it comes to the importance of a particular symptom. Therefore, the purpose of this study was to find out how particular symptoms that are not at a critical level for making a diagnosis may pose problems in adaptation of the general population of elementary school children not diagnosed with ADHD. 


\section{AIMS AND HYPOTHESES OF RESEARCH}

The aim of the study was to identify self-evaluated ADHD symptoms that are critical as adaptation challenges in the general primary school population of students. Three groups of self-evaluated symptoms were examined (hyperactivity, impulsivity and inattention) with respect to academic adjustment (operationalized as school success and academic self-efficacy), social adjustment (operationalized as peer acceptance and social self-efficacy) and emotional adjustment (operationalized as emotional competence and emotional self-efficacy). As previous studies have established age and gender differences in ADHD, the variables age and gender were kept under control when the self-evaluated symptoms of ADHD were tested in general population.

Following the aim of the study, we established three main hypotheses:

H1: Self-evaluated symptom of inattention, in comparison to hyperactivity and impulsivity, will be a better predictor of school maladjustment. Students with higher level of self-evaluated inattention will have lower school success and lower academic self-efficacy.

H2: Self-evaluated symptom of impulsivity, in comparison to hyperactivity and inattention, will be a better predictor of social maladjustment. Students with higher level of self-evaluated impulsivity will have lower peer acceptance and lower social self-efficacy.

H3: Self-evaluated symptom of impulsivity, in comparison to hyperactivity and inattention, will be a better predictor of emotional maladjustment. Students with higher level of self-evaluated impulsivity will have lower emotional competence and lower emotional self-efficacy.

\section{METHODOLOGY}

\section{Participants}

The study included six elementary schools in the regions of Slavonia and Baranja. The participants were students in grades 4, 6 and 8. The total pool of students invited to participate in the study was 896. Parental consent was received for 501 students $(55.92 \%)$. There were 254 male and 247 female students. The age ranged from 10 to 16 years and the average age was 12.72 years $(S D=1.62)$. In the study, only the self-assessment measure of symptoms of ADHD was included, and not the existence of a medical diagnosis, therefore two children with ADHD diagnosis were excluded from the analysis). Table 1 shows the distribution of students by gender, age and grade. 
DRUŠ. ISTRAŽ. ZAGREB GOD. 28 (2019), BR. 3, STR. 503-522

VELKI, T., UŽAREVIĆ, Z., DUBOVICKI, S.:

SELF-EVALUATED ADHD..

○ TABLE 1

Distribution of students by gender, age and grade

\begin{tabular}{llrrl}
\hline Grade & Gender & $\mathrm{f}$ & $\%$ & Average age \\
\hline 4 & boys & 50 & 48 & $M=10.9$ \\
& girls & 54 & 52 & $s d=0.48$ \\
& total & 104 & 20.8 & \\
6 & boys & 91 & 49.2 & $M=12.25$ \\
& girls & 94 & 50.8 & $s d=0.46$ \\
& total & 185 & 36.9 & \\
8 & boys & 112 & 52.6 & $M=14.32$ \\
& girls & 100 & 47.4 & $s d=0.49$ \\
& total & 212 & 42.3 & \\
Total & boys & 254 & 50.7 & $M=12.72$ \\
& girls & 247 & 49.3 & $s d=1.62$ \\
& total & 501 & 100.0 &
\end{tabular}

Hyperactivity - Impulsivity - Attention Scale

(HIP; Vulić-Prtorić, 2006)

The HIP Scale estimates hyperactive and impulsive behavior and the difficulty with focused attention. It consists of 19 items divided into three subscales: hyperactivity (6 items), impulsivity (4 items) and inattention (9 items). The items are statements that describe the most common symptoms of hyperactivity, impulsivity, and inattention. The structure of the HIP Scale was based on a classification system used to measure deficit attention hyperactivity disorder symptoms and for the purpose of theoretical interpretation of ADHD symptomatology. The task of the participant was to decide on the frequency of behaviors they had experienced in the six-month period prior to the study. Accordingly, each item was marked following the 5-point scale: $1=$ never, 2 = rarely, $3=$ sometimes, $4=$ often, $5=$ very often. The result was obtained by calculating the arithmetic mean of selected items. The internal consistency for hyperactivity subscale was Cronbach $\alpha=0.86$, for the impulsivity subscale $\alpha=0.80$ and for the inattention subscale $\alpha=0.88$.

\section{Emotional Competence Questionnaire}

(UEK-45; Takšić, 2002)

The Emotional Competence Questionnaire was used for assessing emotional intelligence as a personality trait. UEK-45 is a short version of the Emotional Intelligence Questionnaire that was created based on the Mayer and Salovey theory (1997). The questionnaire consists of three subscales with a total of 45 items. The subscale 'Ability to observe and understand the emotion' consists of 15 items (e.g. When I see how someone feels, I usually know what happened to them.); the subscale 'Ability to express and name emotions' consists of 14 items 
DRUŠ. ISTRAŽ. ZAGREB GOD. 28 (2019), BR. 3, STR. 503-522

VELKI, T., UŽAREVIĆ, Z., DUBOVICKI, S.:

SELF-EVALUATED ADHD.. (e.g. I can almost always describe my feelings and emotions with words.); and the subscale 'Skills of emotion control and regulation' consists of 16 items (e.g. Even when people around me are in a bad mood, I can keep a good mood.). The task of the participants was to make a subjective judgment on a 5-point scale $(1=$ 'not at all' to $5=$ 'definitely yes') about how strongly the statement refers to them.

\section{Self-Efficacy Questionnaire for Children} (SEQ-C, Vulić-Prtorić \& Sorić, 2006)

Self-Efficacy Questionnaire for Children was designed to measure children's self-efficacy feelings in three domains: academic, emotional and social. The questionnaire consists of 24 items that are divided by efficacy domains. The domain of social self-efficacy $(k=8)$ refers to assertiveness and perceived capacity for relationships with peers, the domain of emotional self-efficacy $(\mathrm{k}=8)$ refers to the ability to face negative emotions, and academic self-efficacy $(k=8)$ refers to the perceived ability for coping with school materials, learning and meeting school expectations. Instructions for the completion of the questionnaire are short and very clear, and the task of the participants is to estimate on the 5-point Likert scale how the behavior described in the statement relates to them (from 1 meaning 'not at all' to 5 meaning 'very well').The overall result is obtained by determining the arithmetic mean of relevant items. Internal consistency in this study was Cronbach $\alpha=0.84$ for the academic self-efficacy subscale, $\alpha=0.80$ for the social self-efficacy subscale and $\alpha=0.79$ for the emotional self-efficacy subscale.

\section{Demographic information}

The participants in the study provided demographic information about themselves: their age, gender and grade, Also, they provided information on their school success (general success at the end of the semi-semester and at the end of the last school year; grade in mathematics at the end of the semi-semester and at the end of the last school year; grade in Croatian language (mother tongue) at the end of the semi-semester and at the end of the last school year). Internal reliability of school success was Cronbach $\alpha=0.79$. Furthermore, they gave data about peer acceptance (2 items on 3-point Likert scale).

After consulting with the schools and getting permission to use the questionnaires, consents from parents were collected. All children who returned a signed parental consent agreed to take part in the research voluntarily. The data collection procedure was conducted in groups and lasted for about 45 
DRUŠ. ISTRAŽ. ZAGREB GOD. 28 (2019), BR. 3, STR. 503-522

VELKI, T., UŽAREVIĆ, Z., DUBOVICKI, S.:

SELF-EVALUATED ADHD.. minutes. It was clearly stated that the participation was anonymous and that there were no (in)correct answers. The importance of providing sincere answers when completing the questionnaire was emphasized. At the beginning of each questionnaire, detailed instructions were given to the participants. If during the data collection procedure it turned out that the question was somewhat unclear, the researcher provided additional explanation individually. The participants were allowed to resign from completion of the questionnaires at any time, but no such cases were recorded.

\section{RESULTS}

(1) TABLE 2

Descriptive statistics for measured variables
Data analysis started with examinations related to the descriptive statistics for the variables included in the study (Table 2). The testing of normality of distribution of major research variables showed no significant deviation from the normal distribution. Asymmetric indexes did not exceed values greater than $+/-2.00$ and parametric statistics was applied.

\begin{tabular}{lcccccrr}
\hline Variables & $\mathrm{N}$ & Min & Max & $M$ & $S D$ & Skewness & Kurtosis \\
\hline Hyperactivity & 501 & 1.00 & 5.00 & 2.28 & 1.02 & 0.737 & -0.282 \\
Impulsivity & 500 & 1.00 & 5.00 & 2.15 & 0.95 & 0.851 & 0.064 \\
Inattention & 500 & 1.00 & 4.78 & 2.14 & 0.89 & 0.657 & -0.462 \\
School success & 501 & 1.67 & 5.00 & 4.09 & 0.80 & -0.582 & -0.578 \\
Academic self-efficacy & 501 & 1.00 & 5.00 & 3.57 & 0.83 & -0.388 & -0.046 \\
Peer acceptance & 501 & 1.00 & 3.00 & 2.62 & 0.50 & -1.217 & 0.812 \\
Social self-efficacy & 501 & 1.00 & 5.00 & 3.74 & 0.74 & -0.601 & 0.467 \\
Emotional competence & 501 & 1.76 & 5.00 & 3.74 & 0.54 & -0.439 & 0.463 \\
Emotional self-efficacy & 501 & 1.00 & 5.00 & 3.38 & 0.83 & -0.196 & -0.311 \\
\hline
\end{tabular}

The possibility of generalization from the data obtained was examined prior to the main analysis. The prevalence of children with self-evaluated symptoms of ADHD was examined. A student was identified as suspected of having ADHD if his/her self-assessment included four or more of the described behaviors (the participant marked four or more items) which occurred to him/her "often" (represented by '4' on the scale) or "very often" (represented by ' 5 ' on the scale). According to this milder criterion of determination of ADHD susceptibility (Biedermann, Petty, Evans, Small, \& Faraone, 2010; Fergusson, Boden, \& Horwood, 2010), 24.6\% of the participants were identified as suspected of having ADHD. Comparison of this finding with the existing studies showed that the prevalence of ADHD susceptibility ranges from $0.8 \%$ to $23.1 \%$ depending on the methodology used (Balázs \& Keresztény, 2013). This led us to the conclusion that the sample of chil- 
$\rightarrow$ GRAPH 1

Average self-evaluated symptoms of ADHD by grade dren suspected of having ADHD in this study is representative of the general population of elementary school children aged 10-16.

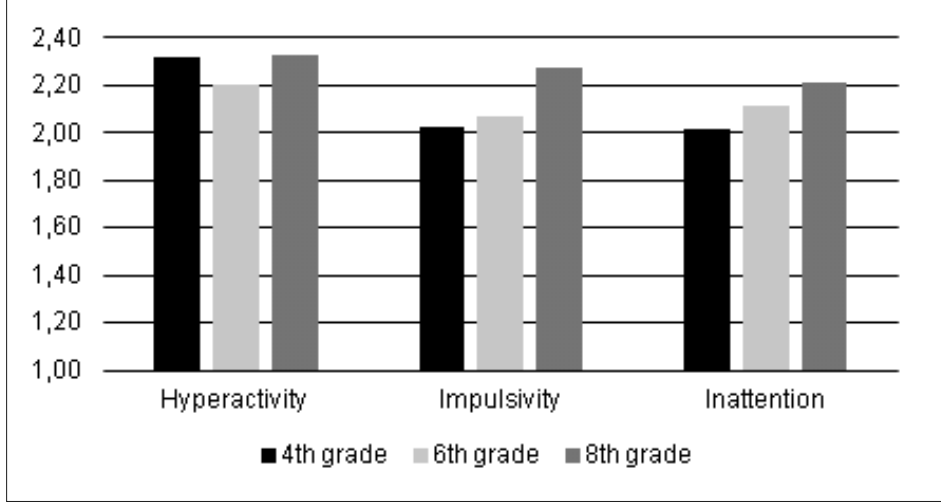

There were no statistically significant age (grade) differences in self-evaluated ADHD symptoms (hyperactivity $\mathrm{F}(2,499)=0.78, p>0.01$; impulsivity $\mathrm{F}(2,499)=3.34, p>0.01$; inattention $\mathrm{F}(2,499)=1.74, p>0.01)$. On average, all students have shown rare self-evaluated symptoms, which is expected because the study included a general population sample (without ADHD diagnosis), not a clinical one.

Since requirements for regression analysis were met, the data were analyzed using hierarchical regression analysis. In step 1, age and gender variables were kept under control, while ADHD symptoms were introduced as predictors of adaptation difficulties in step 2 . Six identical regression analyses were performed, and only the criteria of adjustment were changed.

Inattention proved to be a significant predictor of all of the measured adaptation difficulties, impulsivity showed to be significant only for the prediction of difficulties in academic self-efficacy, and hyperactivity for the prediction of emotional competence problems. By testing the difference in the predictor significance ( $\beta$ coefficients), it was found that inattention was a statistically more significant predictor of academic self-efficacy than impulsivity $(\mathrm{t}(996)=3.95, p<0.001)$, and that inattention was a statistically more significant predictor of emotional competence than hyperactivity $\left(\mathrm{t}_{(996)}=2.95\right.$, $p<0.001)$. As the variables of age and gender were kept under control, ADHD symptoms (hyperactivity, impulsivity and inattention) as predictors of difficulties in students' adaptation were tested for the effect size. However, the effect size for social and emotional adjustment is almost insignificant, whereas a slight to moderate effect size was found for academic adjustment (Cohen's $\mathrm{f}^{2}=0.02-0.07$; Kolesarić \& Tomašić Humer, 2017). 


\begin{tabular}{|c|c|c|c|c|c|c|}
\hline \multirow{3}{*}{$\begin{array}{l}\text { Criteria } \\
\text { Predictors }\end{array}$} & \multicolumn{2}{|c|}{ Academic adjustment } & \multicolumn{2}{|c|}{$\underline{\text { Social adjustment }}$} & \multicolumn{2}{|c|}{ Emotional adjustment } \\
\hline & $\begin{array}{l}\text { School } \\
\text { success }\end{array}$ & $\begin{array}{l}\text { Academic } \\
\text { self-efficacy }\end{array}$ & Peer & $\begin{array}{l}\text { Social } \\
\text { self-efficacy }\end{array}$ & $\begin{array}{l}\text { Emotional } \\
\text { competence }\end{array}$ & Emotional \\
\hline & $\beta$ & & $\beta$ & $\beta$ & & \\
\hline Age & $-0.306^{* *}$ & $-0.168^{* *}$ & 0.060 & 0.016 & 0.038 & -0.055 \\
\hline Gender & $-0.203^{* *}$ & -0.011 & 0.083 & -0.022 & -0.012 & $0.121^{* *}$ \\
\hline \multicolumn{7}{|c|}{ Regression model } \\
\hline$R$ & 0.372 & 0.168 & 0.103 & 0.027 & 0.039 & 0.133 \\
\hline$R^{2}$ & 0.139 & 0.028 & 0.011 & 0.001 & 0.002 & 0.018 \\
\hline$R^{2}$ cor & 0.135 & 0.024 & 0.007 & 0.000 & 0.000 & 0.014 \\
\hline$F(2,498)$ & 39.36 & 7.05 & 2.66 & 0.17 & 0.38 & 4.32 \\
\hline$p$ & $<0.001$ & $<0.001$ & $>0.05$ & $>0.05$ & $>0.05$ & $<0.05$ \\
\hline Age & $-0.283^{* *}$ & $-0.129 * *$ & 0.076 & 0.046 & 0.071 & -0.034 \\
\hline Gender & $-0.186^{* *}$ & 0.019 & $0.094^{*}$ & 0.001 & 0.015 & $0.139 * *$ \\
\hline Hyperactivity & 0.116 & -0.095 & 0.026 & 0.155 & $-0.174^{*}$ & -0.115 \\
\hline Impulsivity & 0.038 & $-0.187^{* *}$ & 0.102 & 0.084 & -0.013 & 0.063 \\
\hline Inattention & $-0.317^{* *}$ & $-0.528^{* *}$ & $-0.269^{* *}$ & $-0.430^{* *}$ & $-0.367^{* *}$ & $-0.225^{* *}$ \\
\hline \multicolumn{7}{|c|}{ Regression model (final solution) } \\
\hline$R$ & 0.426 & 0.511 & 0.214 & 0.268 & 0.254 & 0.309 \\
\hline$R^{2}$ & 0.182 & 0.261 & 0.046 & 0.072 & 0.065 & 0.096 \\
\hline CI & $0.131-0.232$ & $0.206-0.316$ & $0.016-0.075$ & $0.035-0.108$ & $0.030-0.099$ & $0.055-0.136$ \\
\hline$R^{2}$ cor & 0.173 & 0.253 & 0.036 & 0.062 & 0.055 & 0.086 \\
\hline$F(5,495)$ & 21.60 & 33.85 & 4.72 & 7.43 & 6.78 & 10.15 \\
\hline$p$ & $<0.001$ & $<0.001$ & $<0.001$ & $<0.001$ & $<0.001$ & $<0.001$ \\
\hline Cohen's $\mathrm{f}^{2}$ & 0.02 & 0.07 & 0.002 & 0.005 & 0.004 & 0.008 \\
\hline
\end{tabular}

o TABLE 3

Hierarchical regression analysis results

$$
\text { ** } p<0.01 ;{ }^{*} p<0.05
$$

Treating age and gender as control variables, the symptoms of $\operatorname{ADHD}\left(\Delta \mathrm{R}^{2}\right)$ explained the following percentages of the variance of student adjustment: $23.7 \%$ of the variance in academic self-efficacy (inattention and impulsivity), $8.2 \%$ of the variance in emotional self-efficacy (inattention), $7.1 \%$ of the variance in social self-efficacy (inattention), $6.5 \%$ of the variance in emotional competence (inattention and hyperactivity), $4.3 \%$ of the variance in school success (inattention), and $3.5 \%$ of the variance in peer acceptance (inattention).

\section{DISCUSSION}

In line with the study aim, distinctive ADHD symptoms were examined in order to determine best predictors of maladjustment in the general population of elementary school children. Inattention proved to be the best predictor for all three types of maladjustment, that is, problems of academic, social and emotional adjustment. In accordance with the first hypothesis, inattention proved to be the best predictor of school maladjustment. Students with more salient inattention esti- 
DRUŠ. ISTRAŽ. ZAGREB GOD. 28 (2019), BR. 3, STR. 503-522

VELKI, T., UŽAREVIĆ, Z., DUBOVVICKI, S.: SELF-EVALUATED ADHD.. mated lower academic self-efficacy and poorer school success, which is consistent with previous research that pointed out inattention as the key factor affecting academic failure (Barkley, 2000; Pagani et al., 2008; Passolt, 2002; Weyandt \& DuPaul, 2008; Young et al., 2005). The students with attention problems report that they are unable to follow a lecture and copy from the blackboard, their thoughts are often disrupted and wander off, they tend to give up even before they begin working on more complex tasks and perceive themselves as less competent academically (Bussing et al., 2012; Galéra et al., 2009; Velki, 2012). The combination of inattention and impulsivity explains most of the variance in academic self-efficacy, as much as $23.7 \%$, i.e. it is the next significant predictor, which is consistent with some previous studies (Frazier et al., 2007). Furthermore, the students with inattention symptoms and more pronounced symptoms of impulsivity have, generally speaking, more problems in school, especially so if they are more inclined toward aggressive behavior. Studies show that the combination of inattention and impulsivity, which leads to poor academic success, is actually a consequence of the same neurobiological basis, i.e. difficulty in executive functions, short response time and emotional instability (Sjöwall \& Thorell, 2014), thus providing an explanation for poorer academic self-efficacy, which this combination of symptoms leads to. Along with learning difficulties, these students have significant problems in meeting school expectations. By examining the variance explained $(4.3 \%-23.7 \%)$ and the effect size (Cohen's $\left.\mathrm{f}^{2}=0.02-0.07\right)$ more closely, it can be concluded that inattention had the greatest influence on academic maladjustment, which is not surprising given that inattention has proved to be the major risk factor for poorer school success and lower level of academic self-efficacy.

Contrary to the expected, the symptom of inattention was a statistically significant predictor of emotional maladjustment. It is interesting to note that inattention alone explained $8.2 \%$ of the variance in emotional self-efficacy, whereas in combination with hyperactivity, it explained only $6.5 \%$ of the variance in emotional competence. However, the effect size for both aspects of emotional adjustment was very small. Emotional competence refers to the ability to recognize, regulate, and respond to emotionally charged situations. Children who struggle with paying attention have difficulties in recognizing emotions in others, problems with reading facial expression and correct emotional coding, less emotional control as well as problems with focusing on peers during a conversation (Hong et al., 2014; Kristensen et al., 2014; Sjöwall \& Thorell, 2014), all of which lead to additional difficulties in emotional and social functioning. Problems with concentration 
DRUŠ. ISTRAŽ. ZAGREB GOD. 28 (2019), BR. 3, STR. 503-522

VELKI, T., UŽAREVIĆ, Z., DUBOVICKI, S.: SELF-EVALUATED ADHD.. and focusing on their own emotions as well as with recognizing emotions in others lead to a reduced ability to face negative emotions or problems in regulating their negative emotions (Treuting \& Hinshaw, 2001). Emotional self-regulation problems are an additional indicator of poor emotional self- efficacy (Hampel, Manhal, Roos, \& Desman, 2008), which makes it difficult for these children to manage relationships with their peers as well as other close persons in their everyday life.

Based on previous studies (Barkley, 2015; Bartolac, 2013; Defoe et al., 2013; Lachenmeier, 2014) it has been expected that impulsivity would play an important role in predicting social maladjustment, i.e. problems in relationships with peers. However, inattention turned out to be the only significant predictor of problems in social adjustment. Still, it should be taken into account that the effect size in this case was almost insignificant. As previous studies have shown (McQuade \& Hoza, 2015; Velki \& Romstein, 2016), a possible explanation for this finding is that symptoms of impulsivity are significant in predicting aggressive behavior or peer violence, which was not included in the scope of the present study. Problems with following the rules, listening to conversations and engaging in group activities that significantly disturb peer relationships are actually a reflection of symptoms of inattention. Nevertheless, the difficulties perceived in social self-efficacy are only explained by inattention in small portion $(7.1 \%)$. Although they are not always aware of their own negative social status (Diener \& Milich, 1997), this awareness can develop due to a high risk of constant negative peer feedback: the problems of this group of children related to maintaining interest during joint activities, their increased risk to disrupt or interrupt their peers, and their inability to concentrate on play and conversation with peers for a continued period of time lead to the expression of dissatisfaction by their peers. Consequently, their level of social self-efficacy can decrease, i.e. they become aware of the difficulties in establishing and maintaining their peer relationships, which is a very important developmental task during puberty. Furthermore, inattention explained only a small percentage of the variance in peer acceptance $(3.5 \%)$, which is almost insignificant. A possible explanation can be found in the existence of negative balance in peer relations, i.e. inattentive children choose peers and like them more often than their peers who, at the same time, choose them rarely and dislike this particular group of children (Mrug et al., 2009).

The findings of this study point to the fact that a certain proportion of children, without a diagnosed disorder, reported having inattention problems, and therefore having difficulties in everyday functioning. In other words, they mostly have problems in academic, and in some smaller portion in 
DRUŠ. ISTRAŽ. ZAGREB GOD. 28 (2019), BR. 3, STR. 503-522

VELKI, T., UŽAREVIĆ, Z., DUBOVICKI, S.:

SELF-EVALUATED ADHD.. social and emotional adaptation. Subjective experience of the child's difficulties plays an important role in his/her adaptation. Although children in the general population with more salient inattention had emerged in this study as children with the most difficulties in academic adjustment, the social and emotional functioning of these children was disrupted as well. Since the study includes the general population of children, and not those diagnosed with ADHD, prevention should become a part of formal education. A reduced feeling of self-efficacy, the result of more salient self-evaluated symptoms of ADHD, has a negative impact on child development. As an educational institution, the school needs to attend to these problems: it needs to deal with not only academic difficulties children may have but also with socio-emotional issues that may be more important for the student's adaptive functioning since they can mediate academic difficulties too. Working on issues of inattention, increasing concentration, and attention focus on key aspects in both academic work and relations with peers, where these problems affect socio-emotional adaptation, will greatly help students in further development and work. These findings should be implemented in school prevention programs, especially because of the long-lasting effect on academic life and personal life of students. In accordance with some previous studies, the main problems with inattention persist throughout the students' education. In high school and college, attention deficit has the most negative influence on academic and social functioning and on learning habits and learning skills (Norvilitis et al., 2010; Norwalk et al., 2009; Pagani et al., 2008). For students with particularly prevalent problems with inattention symptoms, it was possible to predict academic problems even at the end of the first year of study (Frazier et al., 2007). In order to prevent these negative influences of attention deficits, primary schools should incorporate in their curriculum everyday activities, i.e. organize class and activities in a way that all students could benefit from. First of all, teachers should have proper education about the symptoms and consequences of attention deficit while at university. This is important not just for recognizing the symptoms of inattention, but to learn how to prevent inattention of students in the classroom. Future teachers should learn during their studies how to provide a diversity of activities that would engage different children (for example using different types of games during regular classes so that all students could benefit) or how to teach self-control of impulses to children (for example, waiting in line for lunch during break or waiting to be picked to play). Secondly, proper class organization, without unnecessary distractions and which enables constant supervision of teachers, 
DRUŠ. ISTRAŽ. ZAGREB GOD. 28 (2019), BR. 3, STR. 503-522

VELKI, T., UŽAREVIĆ, Z., DUBOVICKI, S.: SELF-EVALUATED ADHD.. could benefit all students. Each student is an individual with different needs, and only inclusive education can help all students use their full potential. For example, some students react better to visual stimulants (like pictures with classroom rules) and others to verbal instruction (like students' repetition out loud of the assignment given by the teacher). Additionally, it is important that teachers clearly communicate classroom rules and behavioral expectations to all students. Classroom routine helps all children prepare for upcoming tasks, gives them structure and helps them to develop planning strategies. Furthermore, educational technology in the classroom could help with attention problems. All children generally respond very well to new technologies, which require a certain degree of attention and concentration but in an interesting and acceptable way. New technologies, such as computers, tablets and smartphones, give them immediate feedback on the task which has great positive impact on their work. Using educational games, creating cognitive maps in special applications, writing tasks, and seeking additional information through modern technologies (which, in contrast to classical literature, provides video and audio information) can be an extremely useful tool in day-to-day work with all children. There are creative and well-designed computer games, which have characteristics that may help in the development of certain skills of the child (for example, Tetris is an exceptionally good game for the development of logical thinking, visual representation, and depending on the type of $2 \mathrm{D}$ or $3 \mathrm{D}$ rotation, spatial abilities and concentration). Teachers need to clearly define what type of information or teaching material they want their students to master, and then ensure that an adequate application or computer game is used by students for learning and not only for fun during class (Velki, 2018).

Methodological limitations of the research carried out should be taken into account in the interpretation of results. Data pertaining to the variables were gathered solely through student self-assessment. A subjective assessment of difficulties and problems a child experiences is extremely important because as the child becomes aware of problems with adaptation, regardless of a more objective assessment of the environment, it is necessary to work with the child on the problems detected. However, the importance of self-estimated symptoms and difficulties for overall adjustment is questionable. It would be interesting to examine levels of agreement between students' assessments of symptoms and different aspects of adjustment with assessments of their teachers or peers. Additionally, the study was conducted on a general elementary school-age population, excluding those diagnosed with ADHD. Since the aim of the research was to identify difficul- 
DRUŠ. ISTRAŽ. ZAGREB GOD. 28 (2019), BR. 3, STR. 503-522

VELKI, T., UŽAREVIĆ, Z., DUBOVICKI, S.: SELF-EVALUATED ADHD.. ties that some ADHD symptoms may cause in the general population of students at elementary level, it would be interesting to compare the findings with those about the contribution of ADHD symptoms in students with an official diagnosis to difficulties in adapting to the school environment. Furthermore, the response rate of the study's participants was only $55.92 \%$, which allows for the possibility that there are students with more problems and difficulties who did not participate in the study due to a missing parental consent. In the future, a greater response rate of participants and a wider age range would be beneficial. Also, students with an ADHD diagnosis should be included in order to compare contributions of particular ADHD symptoms on all adaptation measures for both groups of students, those with and without an ADHD diagnosis.

\section{CONCLUSION}

\section{REFERENCES}

Attention difficulties have been detected as a major problem in all aspects of student adaptation at elementary-school level. Academic adjustment of students is mostly hindered by inattention which, in addition, creates problems in social and emotional adjustment. The students without an ADHD diagnosis or attention deficit who reported more inattention difficulties are at risk for developing a number of difficulties in their everyday functioning. As an educational institution, the school has a key role in preventing the problem of students' adaptation and it is crucial that addressing these issues should start at the very beginning of formal education.

August, G. J., Ostrander, R., \& Bloomquist, M. J. (1992). Attentiondeficit hyperactivity disorder - an epidemiologic screening method. American Journal of Orthopsychiatry, 62(3), 387-396. https://doi.org/10. 1037/h0079354

Balázs, J., \& Keresztény, Á. (2013). Subthreshold attention deficit hyperactivity in children and adolescents: A systematic review. European Child and Adolescent Psychiatry, 23(6), 393-408. https://doi.org/ 10.1007/s00787-013-0514-7

Barkley, R. A. (2015). Emotional dysregulation is a core component of ADHD. In R. A. Barkley (Ed.), Attention-Deficit Hyperactivity Disorder (pp. 122-166). New York \& London: The Guilford Press.

Barkley, R. A. (2000). Taking charge of ADHD. New York, NY: The Guilford Press.

Bartolac, A. (2013). Socijalna obilježja svakodnevnog života djece i mladih s ADHD-om (Social aspects of everyday life of children and youth with ADHD). Ljetopis socijalnog rada, 20(2), 269-300.

Biederman, J., Mick, E., Faraone, S. V., Braaten, E., Doyle, A., Spencer, T., Wilens, T. E., Frazier, E., \& Johnson, M. A. (2002). Influence of gender 
DRUŠ. ISTRAŽ. ZAGREB GOD. 28 (2019), BR. 3, STR. 503-522

VELKI, T., UŽAREVIĆ, Z., DUBOVICKI, S.: SELF-EVALUATED ADHD.. on attention deficit hyperactivity disorder in children referred to a psychiatric clinic. American Journal of Psychiatry, 159(1), 36-42. https://doi. org/10.1176/appi.ajp.159.1.36

Biederman, J., Petty, C. R., Evans, M., Small, J., \& Faraone, S. V. (2010). How persistent is ADHD? A controlled 10-year follow-up study of boys with ADHD. Psychiatry Research, 177(3), 299-304. https://doi.org/ 10.1016/j.psychres.2009.12.010

Brown, A. J., \& Casey, B. M. (2016). Subclinical ADHD-symptoms are associated with executive-functioning and externalizing problems in college students without ADHD-diagnoses. Journal of Educational and Developmental Psychology, 6(1), 204-220. https://doi.org/10.5539/jedp. v6n1p204

Bussing, R., Mason, D. M., Bell, L., Porter, P., \& Garvan, C. (2010). Adolescent outcomes of childhood attention-deficit/hyperactivity disorder in a diverse community sample. Journal of the American Academy of Child and Adolescent Psychiatry, 49(6), 595-605. https://doi. org/10.1016/j.jaac.2010.03.006

Bussing, R., Porter, P., Zima, B. T., Mason, D., Garvan, C., \& Reid, R. (2012). Academic outcome trajectories of students with ADHD: Does exceptional education status matter? Journal of Emotional and Behavioral Disorders, 20(3), 131-143. https://doi.org/10.1177/1063426610388180

Cantwell, D. P. (1996). Attention deficit disorder: a review of the past 10 years. Journal of the American Academy of Child and Adolescent Psychiatry, 35(8), 978-987. https://doi.org/10.1097/00004583-199608000-00008

Cho, S. C., Kim, B. N., Kim, J. W., Rohde, L. A., Hwang, J. W., Chungh, D. S., Shin, M. S., Lyoo, I. K., Go, B. J., Lee, S. E., \& Kim, H. W. (2009). Full syndrome and subthreshold attention-deficit/hyperactivity disorder in a Korean community sample: Comorbidity and temperament findings. European Children Adolescence Psychiatry, 18(7), 447-457. https://doi.org/10.1007/s00787-009-0755-7

Corkum, P., Corbin, N., \& Pike, M. (2010). Evaluation of a school-based social skills program for children with Attention-Deficit/Hyperactivity Disorder. Child \& Family Behavior Therapy, 32(2), 139-151. https://doi.org/10.1080/07317101003776472

Defoe, I. N., Farrington, D. P., \& Loeber, R. (2013). Disentangling the relationship between delinquency and hyperactivity, low achievement, depression, and low socioeconomic status: Analysis of repeated longitudinal data. Journal of Criminal Justice, 41(2), 100-107. https://doi. org/10.1016/j.jcrimjus.2012.12.002

Diener, M. B., \& Milich, R. (1997). Effects of positive feedback on the social interactions of boys with attention deficit hyperactivity disorder: A test of the self-protective hypothesis. Journal of Clinical Child Psychology, 26(3), 256-265. http://dx.doi.org/10.1207/s15374424jccp2603_4

DuPaul, G. J., \& Langberg, J. M. (2015). Educational impairments in children with ADHD. In R. A. Barkley (Ed.), Attention-Deficit Hyperactivity Disorder: A handbook for diagnosis and treatment (pp. 234-263). New York \& London: The Guilford Press.

Fergusson, D. M., Boden, J. M., \& Horwood, L. J. (2010). Classification of behavior disorders in adolescence: Scaling methods, pre- 
DRUŠ. ISTRAŽ. ZAGREB GOD. 28 (2019), BR. 3, STR. 503-522

VELKI, T., UŽAREVIĆ, Z., DUBÓVICKI, S.: SELF-EVALUATED ADHD. dictive validity, and gender differences. Journal of Abnormal Psychology, 119(4), 699-712. https://doi.org/10.1037/a0018610

Frazier, T. W., Youngstrom, E. A., Glutting, J. J., \& Watkins, M. W. (2007). ADHD and achievement: Meta-analysis of the child, adolescent, and adult literatures and a concomitant study with college students. Journal of Learning Disabilities, 40(1), 49-65. https://doi.org/10.1177/00 222194070400010401

Galéra, C., Melchior, M., Chastang, J. F., Bouvard, M. P., \& Fombonne, E. (2009). Childhood and adolescent hyperactivity-inattention symptoms and academic achievement 8 years later: The GAZEL Youth study. Psychological Medicine, 39(11), 1895-1906. https://doi.org/10.1017/ S0033291709005510

Gershon, J. (2002). A meta-analytic review of gender differences in ADHD. Journal of Attention Disorders, 5(3), 143-154. https://doi.org/10. 1177/108705470200500302

Groen, Y., den Heijer, A. E., Fuermaier, A. B. M., Althaus, M., \& Tucha, O. (2018). Reduced emotional empathy in adults with subclinical ADHD: Evidence from the empathy and systemizing quotient. ADHD Attention Deficit Hyperactive Disorder, 10(2), 141-150. https://doi.org/ 10.1007/s12402-017-0236-7

Gudjonsson, G. H., Sigurdsson, J. F., Eyjolfsdottir, G. A., Smari, J., \& Young, S. (2009). The relationship between satisfaction with life, ADHD symptoms, and associated problems among university students. Journal of Attention Disorders, 12(6), 507-515. https://doi.org/10. $1177 / 1087054708323018$

Hampel, P., Manhal, S., Roos R., \& Desman C. (2008). Interpersonal coping among boys with ADHD. Journal of Attention Disorder, 11(4), 427-450. https://doi.org/10.1177/1087054707299337

Hong, S. B., Dwyer, D., Kim, J. W., Park, E. J., Shin, M. S., Kim, B. N., Yoo, H. J., Cho, I. H., Bhang, S. Y., Hong, Y. C., Pantelis, C., \& Cho, S. C. (2014). Subthreshold attention-deficit/hyperactivity disorder is associated with functional impairments across domains: A comprehensive analysis in a large-scale community study. European Child and Adolescent Psychiatry, 23(8), 627-636. https://doi.org/10.1007/s00787-013-0501-z

Kolesarić, V., \& Tomašić Humer, J. (2017). Veličina učinka (Effect size). Osijek: Sveučilište Josipa Jurja Strossmayera u Osijeku, Filozofski fakultet.

Kristensen, H. A., Parker, J. D. A., Taylor, R. N., Keefer, K. V., Kloosterman, P. H., \& Summerfeldt, L. J. (2014). The relationship between trait emotional intelligence and ADHD symptoms in adolescents and young adults. Personality and Individual Differences, 65, 36-41. https://doi.org/ 10.1016/j.paid.2014.01.031

Lachenmeier, H. (2014). Selbstwertwahrnehmung bei ADHS Erwachsener (ADHD adults' perception of their self-esteem). Schweizer Archiv für Neurologie, Psychiatrie und Psychotherapie, 165(2), 47-53. https://doi.org/10.4414/sanp.2014.00230

McQuade, J. D., \& Hoza, B. (2015). Peer relationships of children with ADHD. In R. A. Barkley (Ed.), Attention-Deficit Hyperactivity Disorder (pp. 288-305). New York \& London: The Guilford Press. 
DRUŠ. ISTRAŽ. ZAGREB GOD. 28 (2019), BR. 3, STR. 503-522

VELKI, T., UŽAREVIĆ, Z., DUBÓVICKI, S.: SELF-EVALUATED ADHD..
Moldavsky, M., Groenewald, C., Owen, V., \& Sayal, K. (2012). Teachers' recognition of children with ADHD: Role of subtype and gender. Child and Adolescent Mental Health, 18(1), 18-23. https://doi.org/ 10.1111/j.1475-3588.2012.00653.x

Mrug, S., Hoza, B., Gerdes, A. C., Hinshaw, S., Arnold, L. E., Hechtman L., \& Pelham, W. E. (2009). Discriminating between children with ADHD and classmates using peer variables. Journal of Attention Disorder, 12(4), 372-389. https://doi.org/10.1177/1087054708314602

Norén Selinus, E., Molero,Y., Lichtenstein, P., Anckarsäter, H., Lundström, S., Bottai, M., \& Hellner Gumpert, C. (2016). Subthreshold and threshold attention deficit hyperactivity disorder symptoms in childhood: Psychosocial outcomes in adolescence in boys and girls. Acta Psychiatrica Scandinavica, 134(6), 533-545. https://doi. org/10.1111/acps.12655

Norvilitis, J. M., Sun, L., \& Zhang, J. (2010). ADHD symptomatology and adjustment to college in China and the United States. Journal of Learning Disabilities, 43(1), 86-94. https://doi.org/10.1177/00222194093 45012

Norwalk, K., Norvilitis, J., \& MacLean, M. G. (2009). ADHD symptomatology and its relationship to factors associated with college adjustment. Journal of Attention Disorders, 13(3), 251-258. https://doi.org/ 10.1177/1087054708320441

Pagani, L., Vitaro, F., Tremblay, R., McDuff, P., Japel, C., \& Larose, S. (2008). When predictions fail: The case of unexpected pathways toward high school dropout. Journal of Social Issues, 64(1), 175-194. https://doi. org/10.1111/j.1540-4560.2008.00554.x

Passolt, M. (2002). Hiperaktiven otrok: psihomotorična terapija (The hyperactive child: Psychomotor therapy). Ljubljana: Sožitje.

Quinn, P., \& Wigal, S. (2004). Perceptions of girls and ADHD: Results from a National Survey. Medscape General Medicine, 6(2), 2.

Ramtekkar, U. P., Reiersen, A. M., Todorov, A. A., \& Todd, R. D. (2010). Sex and age differences in attention-deficit/hyperactivity disorder symptoms and diagnoses: Implications for DSM-V and ICD-11. Journal of the American Academy of Child and Adolescent Psychiatry, 49(3), 217-228. https://doi.org/10.1016/j.jaac.2009.11.011

Rielly, N. E., Craig, W. M., \& Parker, K. C. (2006). Peer and parenting characteristics of boys and girls with subclinical attention problems. Journal of Attention Disorders, 9(4), 598-606. https://doi.org/10.1177/ 1087054705284245

Rucklidge, J. J. (2010). Gender differences in attention-deficit/hyperactivity disorder. Psychiatric Clinics of North America, 33(2), 357-373. https://doi.org/10.1016/j.psc.2010.01.006

Sjöwall, D., \& Thorell, L. B. (2014). Functional impairments in Attention Deficit Hyperactivity Disorder: The mediating role of neuropsychological functioning. Developmental Neuropsychology, 39(3), 187-204. https://doi.org/10.1080/87565641.2014.886691

Takšić, V. (2002). Upitnici emocionalne inteligencije (kompetentnosti) (The questionnaires of emotional intelligence and competence). In K. Lacković-Grgin, A. Proroković, V. Ćubela, \& Z. Penezić (Eds.), Zbirka psihologijskih skala i upitnika (Collection of psychological scales and questionnaires) (pp. 27-45). Zadar: Filozofski fakultet u Zadru. 
DRUŠ. ISTRAŽ. ZAGREB GOD. 28 (2019), BR. 3, STR. 503-522

VELKI, T., UŽAREVIĆ, Z., DUBÓVICKI, S.: SELF-EVALUATED ADHD..
Todd, R. D., Sitdhiraksa, N., Reich, W., Ji, T. H., Joyner, C. A., Heath, A. C., \& Neuman, R. J. (2002). Discrimination of DSM-IV and latent class attention-deficit/hyperactivity disorder subtypes by educational and cognitive performance in a population-based sample of child and adolescent twins. Journal of the American Academy of Child and Adolescent Psychiatry, 41(7), 820-828. https://doi.org/10.1097/00004583200207000-00014

Treuting, J. J., \& Hinshaw, S. P. (2001). Depression and self-esteem in boys with attention deficit/hyperactivity disorder: Associations with comorbid aggression and explanatory attributional mechanisms. Journal of Abnormal Child Psychology, 29, 23-39. https://doi.org/10.1023/ A:1005247412221

Velki, T. (2012). Priručnik za rad s hiperaktionom djecom u školi (Handbook for working with hyperactive children in school). Jastrebarsko: Naklada Slap.

Velki, T. (2018). Priručnik za rad s hiperaktionom djecom u školi (Handbook for working with hyperactive children in school), 2. prošireno izdanje. Jastrebarsko: Naklada Slap.

Velki, T., \& Dudaš, M. (2016). Pokazuju li hiperaktivnija djeca više simptoma agresivnosti? (Do more hyperactive children show more symptoms of aggression?). Ljetopis socijalnog rada, 23(1), 87-121. https:// doi.org/10.3935/ljsr.v23i1.93

Velki, T., \& Romstein, K. (2016). Povezanost samoprocijenjenih simptoma ADHD-a s agresivnim ponašanjem i sudjelovanjem u vršnjačkom nasilju učenika osnovnoškolske dobi (The correlation of self-evaluated ADHD symptoms with aggressive behavior and participation in peer violence among children in primary schools). Hrvatska revija za rehabilitacijska istraživanja, 52(2), 30-41. https://doi.org/10.31299/hrri. 52.2 .4

Velki, T., \& Vrdoljak, G. (2019). Gender as moderator and age as mediator variables in prediction of school adjustment by self-evaluated symptoms of ADHD. Primenjena psihologija, 12(1), 65-83. https://doi. org/10.19090/pp.2019.1.65-83

Vulić-Prtorić, A. (2006). Skala hiperaktivnosti - impulzivnosti - pažnje - HIP (Hyperactivity-impulsivity-attention scale). In V. Ćubela Adorić, A. Proroković, Z. Penezić, \& I. Tucak (Eds.), Zbirka psihologijskih skala i upitnika - Svezak 3 (Collection of psychological scales and questionnaires, Vol. 3) (pp. 41-49). Zadar: Sveučilište u Zadru.

Vulić-Prtorić, A., \& Sorić, I. (2006). Upitnik samoefikasnosti za djecu SEQ-C (Self-efficacy questionnaire for children). In V. Ćubela Adorić, A. Proroković, Z. Penezić, \& I. Tucak (Eds.), Zbirka psihologijskih skala i upitnika - Svezak 3 (Collection of psychological scales and questionnaires, Vol. 3) (pp. 87-93). Zadar: Sveučilište u Zadru.

Weyandt, L. L., \& DuPaul, G. J. (2008). ADHD in college students: Developmental Findings. Developmental Disabilities Research Reviews, 14(4), 311-319. https://doi.org/10.1002/ddrr.38

Young, S., Heptinstall, E., Sonuga-Barke, E. J. S., Chadwick, O., \& Taylor, E. (2005). The adolescent outcome of hyperactive girls: Self-report of psychosocial status. Journal of Child Psychology and Psychiatry, 46(3), 255-262. https://doi.org/10.1111/j.1469-7610.2004.00350.x 
DRUŠ. ISTRAŽ. ZAGREB GOD. 28 (2019), BR. 3, STR. 503-522

VELKI, T., UŽAREVIĆ, Z., DUBOVICKI, S.:

SELF-EVALUATED ADHD..
Samoprocijenjeni simptomi ADHD-a kao rizični čimbenici prilagodbe u osnovnoi školi

Tena VELKI, Zvonimir UŽAREVIĆ, Snježana DUBOVICKI

Fakultet za odgojne i obrazovne znanosti, Osijek

Prijašnja su istraživanja pokazala kako učenici koji pokazuju simptome ADHD-a ujedno imaju i više problema u svim aspektima prilagodbe. Cili je istraživanja provjeriti koji simptomi ADHD-a predviđaju probleme u prilagodbi opće populacije učenika. Hiperaktivnost, impulzivnost i nepažanja ispitane su u odnosu na akademsku, socijalnu i emocionalnu prilagodbu. $U$ istraživanju je sudjelovao 501 učenik (prosječne dobi $M=12,72, S D=1,62$ ). Uzeti su u obzir sljedeći instrumenti: Skala hiperaktivnosti-impulzivnosti-pažnje, Upitnik emocionalne kompetentnosti, Upitnik samoefikasnosti te samoprocjena osjećaja vršnjačke prihvaćenosti i školski uspjeh. Nepažnja se pokazala kao značajan predikłor problema u svim aspektima prilagodbe (akademskoi $(\beta=-0,317$; $\beta=-0,528 ; p<0,001)$, socijalnoi $(\beta=-0,269 ; \beta=-0,430$; $p<0,001)$ i emocionalnoi prilagodbi $(\beta=-0,225$; $\beta=-0,367 ; p<0,01)$ ), impulzivnost samo u akademskoj samoefikasnosti $(\beta=-0,187, p<0,01)$, a hiperaktivnost samo $u$ emocionalnoj kompetentnosti $(\beta=-0,174, p<0,05)$. Budući da se nepažnja pokazala kao dominantan problem, stručnjaci koji rade s djecom trebaju raditi na jačanju pažnje i koncentracije kod svih učenika kao na prevenciji za probleme $u$ prilagodbi.

Ključne riječi: hiperaktivnost, impulzivnost, nepažnja, akademska prilagodba, socijalna prilagodba, emocionalna prilagodba

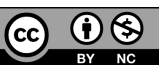

Međunarodna licenca / International License: Imenovanje-Nekomercijalno/ Attribution-NonCommercial 